\title{
Captive broodstock development of common carp Cyprinus carpio Linnaeus, 1758: influence of age on spermatogenesis and fertilisation parameters
}

\author{
C. JUDITH BETSY ${ }^{1}$, J. STEPHEN SAMPATH KUMAR ${ }^{2}$, K. THILAK PON JAWAHAR ${ }^{3}$, \\ S. ATHITHAN ${ }^{1}$, B. AHILAN ${ }^{1}$ AND K. KARAL MARX ${ }^{1}$ \\ ${ }^{1}$ Department of Inland Aquaculture, Fisheries College and Research Institute, Tamil Nadu Fisheries University, \\ Thoothukudi - 628 001, Tamil Nadu, India \\ ${ }^{2}$ Centre for Sustainable Aquaculture, Tamil Nadu Fisheries University, Nagapattinam - 611 001, Tamil Nadu, India \\ ${ }^{3}$ Department of Animal Genetics and Breeding, Veterinary College and Research Institute, Tamil Nadu Animal sciences \\ and Veterinary University, Tirunelveli - 627 001, Tamil Nadu, India \\ e-mail: betsyjudith@gmail.com
}

\begin{abstract}
Knowledge on the quality of male and female gametes which may affect fertilisation success and larval survival is necessary to enhance fish production to meet global demand. Gamete quality is affected by factors like sex ratio, stocking density, age, size, nutrition and feeding regime. In the present study, the spermatological and fertilisation parameters as influenced by the age of brooders of Cyprinus carpio Linnaeus 1758 developed under captive condition from a single population were studied with special reference to dilution ratios. Milt was collected from 6, 12 and 18 months old brooders of C. carpio and diluted at three ratios viz., 1:40, 1:80 and 1:120 using freshwater fish saline. Sperm density, spermatocrit value, seminal plasma composition, motility duration, fecundity, fertilisation and hatching rates were studied for brooders of all age groups. The results showed that milt from 12 months old brooder produced good quality milt in terms of motility duration $(69.66 \pm 4.72 \mathrm{sec})$, fertilisation rate $(91.3 \pm 3.05 \%)$ and hatching rate $(76.5 \pm 2.64 \%)$ at $1: 40$ dilution ratio.
\end{abstract}

Keywords: Age, Common carp, Dilution ratio, Fertilisation, Spermatogenesis

\section{Introduction}

Common carp Cyprinus carpio Linnaeus 1758 is a highly preferred food fish and cultured worldwide. During 2013, the production of C. carpio was 4 million $\mathrm{t}$ (FAO, 2015) and ranked third globally.Common carp spawns throughout the year in tropical areas, with peaks in January-March and July-August. In wild condition, carps are partial spawners whereas domesticated carps release all their mature eggs within a few hours.

The quality of male and female gametes may affect fertilisation success and larval survival (Rurangwa et al., 2004). Generally, the sperm motility, sperm concentration, egg diameter, fertilisation rate and hatching rate are used as indices of gamete quality (Aliniya et al., 2013). Motility parameters are used to evaluate the quality of the spermatozoa (Billard et al., 1995). Spermatozoa motility, milt volume and sperm concentration are considered as good indicators of milt quality (Cabrita et al., 2001; Tekin et al., 2003). The quality of fish eggs is generally determined by their fertilisation rate and hatchling survival. Good quality eggs exhibit low mortality levels at fertilisation, hatching and first feeding (Brooks et al., 1997). Poor quality eggs have delayed cortical reaction and slow rise in osmolarity after fertilisation (Kjorsvik and Lonning, 1983).

The age of broodstock influences the quality of the gametes produced. Although there are no strong evidences or reports on the changes in the quantity of spermatozoa at different age, many researchers reported decreased relative fecundity in female fishes as age advances (Siraj et al., 1983; Springate et al., 1984). The age of broodstock also affects the success of sperm storage. According to Tempero et al. (2006), age at maturity in common carp is related to latitude and sex. They also stated that males mature before females and fish mature earlier at low latitudes compared to higher latitudes. Parameswaran et al. (1972) reported that in pond culture in India, males mature at 6 months of age and females at 8 months.

Considerable variations occur in the spermatological quality of milt collected from one individual at different times of the same season. Factors such as age, health status, physiological condition and maturity stage are known to play a role in the milt quality and reproductive 
performance of a species (Buyukhatipoglu and Holtz, 1984; Trippel and Neilson, 1992; Vuthiphandchai and Zohar, 1999). The present study aimed at evaluating the effect of different age group of brooders on the spermatological and fertilisation parameters to identify the right age group for breeding.

\section{Materials and methods}

\section{Seed stocking and broodstock development}

Earthen pond of 0.1 ha $(50 \times 20 \mathrm{~m})$ was used for the broodstock development and rearing. The pond was stocked with C. carpio fingerlings of 40 days age $(5 \pm 1.3 \mathrm{~g})$. The fishes were grown for a period of one and a half years. Mature fishes were selected based on the identification features described by Thomas et al. (2003). The selected 20 males and 20 females were stocked separately in low cost net cages $(5 \times 3 \times 3 \mathrm{ft})$ erected in the pond at a density of $1 \mathrm{~kg}$ per $\mathrm{m}^{3}$ of water, following Secer et al. (2004).

\section{Milt collection}

Milt was collected and processed from 5 brooders of C. carpio once they reached 6 months age $(137.07 \pm 2.58 \mathrm{~g}$; $17.28 \pm 1.22 \mathrm{~cm})$. Subsequently, the same brooders were used as donors for milt after 12 months $(319.28 \pm 20.17 \mathrm{~g}$ and $26.24 \pm 2.65 \mathrm{~cm})$ and 18 months $(507.85 \pm 27.3 \mathrm{~g}$ and $30.53 \pm 1.75 \mathrm{~cm})$. The donor adults with oozing milt on mild pressing of abdomen were given hormonal inducement using WOVA-FH @ $0.5 \mathrm{ml} \mathrm{kg}^{-1}$ of body weight intramuscularly at the base of the dorsal fin during early hours of the day. Milt collection was done by gentle stripping as described by Kurokura et al. (1984) and Lubzens et al. (1997).

\section{Spermatological parameters of milt}

The volume of milt $(\mathrm{ml})$ was directly determined from the graduations in the cryovials following Aral et al. (2007). Colour of milt was determined by visual observation. Samples of $100 \mu 1$ were drawn from fresh milt for evaluation of $\mathrm{pH}$ using $\mathrm{pH}$ indicator strips $(\mathrm{pH}$ : 6.5-10; Merck, Germany) (Akcay et al., 2004; Bozkurt et al., 2012).

The collected milt was analysed under NIKON E360 microscope using phase contrast objective for estimating sperm density and motility duration. In order to estimate these parameters, milt was diluted with freshwater fish saline (FFS) at dilution ratios of 1:40, 1:80 and 1:120. Suitable motility scores were also assigned following Betsy and Stephen (2014). Sperm density was estimated using haemocytometer (NAUBAEUR, Germany) as described by Hafez (1987). Quality of the spermatozoa in the milt was evaluated by observation of their motility by placing $1 \mu l$ of diluted milt sample and $1 \mu l$ of tap water on glass slide and observing under microscope (Secer et al., 2004). Spermatocrit value was estimated following Verma et al. (2009) and expressed as percentage.

The seminal plasma collected after centrifugation of the milt at $1000 \mathrm{~g}$ for $10 \mathrm{~min}$ (Secer et al., 2004). were used for estimation of magnesium and calcium content in Spectroquant NOVA 60 (Merck, Germany) using Photometric cell test kits (Merck, Germany).

\section{Artificial fertilisation}

Dry method of in vitro fertilisation was employed following Sultana et al. (2010) and Aliniya et al. (2013). Fresh milt was collected from the fishes of 6, 12 and 18 months age groups and fertilised with the fresh milt which was diluted with FFS at dilution ratios of 1:40, 1:80 and 1:120. Eggs from single female was collected and divided into 3 batches and each batch contained approximately 500 eggs. Batches of eggs were inseminated with fresh milt samples. The sperm-egg ratio was approximately 250000 sperm per egg (Aliniya et al., 2013). Fertilisation was done in dry plastic dishes. The fertilisation rate and hatching rates were calculated following Bromage and Cumaranatunga (1988) and Hanjavanit et al. (2008) respectively.

\section{Statistical analysis}

The data were statistically analysed by ANOVA in SPSS 20 software.

\section{Results}

The milt was milky white in appearance and the $\mathrm{pH}$ varied from 7-8. Volume of milt collected from C. carpio brooders of three different age groups ranged between 2-2.5 $\mathrm{ml}$ and the density of milt varied considerably between the three age groups. Significant variations $(p<0.05)$ were noticed among the dilution ratios also. From Fig. 1, it can be seen that the mean highest density of $1.107 \pm 0.13 \times 10^{10}$ cells $\mathrm{ml}^{-1}$ was recorded in 6 month age group brooders when diluted at a ratio of 1:40.

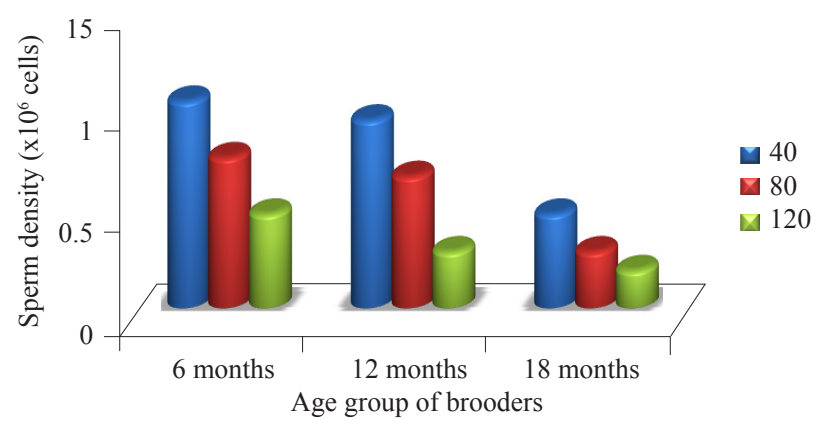

Fig. 1. Relation between age group, dilution ratios and density of C. carpio spermatozoa 
Highest $(<0.05)$ spermatocrit value was observed for milt collected from 6 months old brooder $(84 \pm 2.5 \%)$ while the lowest value of $73 \pm 1.5 \%$ was found in 18 months old brooder (Fig. 2). The $\mathrm{Ca}^{2+}$ and $\mathrm{Mg}^{2+}$ levels in the seminal plasma of common carp significantly $(p<0.05)$ increased as age increased. (Table 1).

Fecundity varied significantly between brooders of the three age groups as depicted in Fig. 3. The lowest fecundity (71 eggs per g body weight of fish) was observed in 6 months old brooder, whereas, 18 months old brooder had highest fecundity of 162 eggs per $\mathrm{g}$ body weight.

The mean motility duration of fresh milt collected from 6,12 and 18 months old brooders were $65.89 \pm 1.52$, $73 \pm 2$ and $62.33 \pm 1.02 \mathrm{sec}$ respectively with motility score of 10 and $100 \%$ live cells (Table 1). However, from Table 2 it is evident that the initial mean motility duration

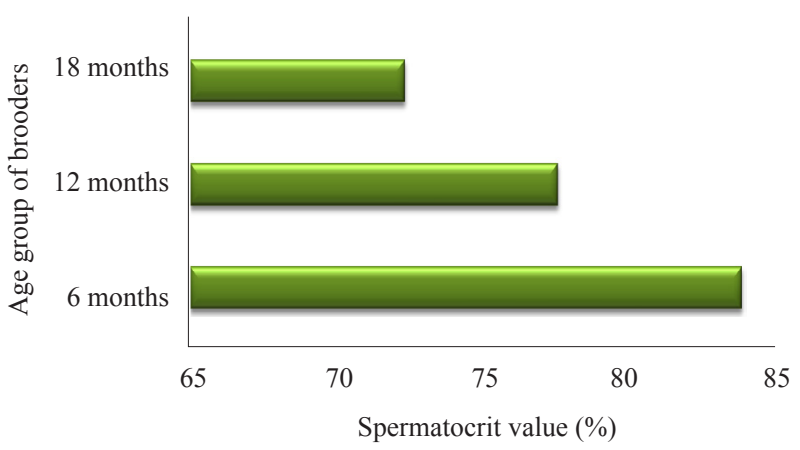

Fig. 2. Spermatocrit value (\%) of milt collected from three age group brooders of C. carpio

Table 1. Spermatological parameters of fresh milt collected from common carp brooders of three age groups

\begin{tabular}{llll}
\hline \multirow{2}{*}{ Parameters } & \multicolumn{3}{c}{ Age group } \\
\cline { 2 - 4 } & 6 months & 12 months & 18 months \\
\hline Motility duration (sec) & $65.89 \pm 1.52$ & $73 \pm 2$ & $62.33 \pm 1.02$ \\
Motility score & 10 & 10 & 10 \\
Live cells (\%) & 100 & 100 & 100 \\
Dead cells (\%) & 0 & 0 & 0 \\
Spermatocrit value (\%) & 84 & 78 & 73 \\
Calcium (mg l-1) & 57 & 64 & 69 \\
Magnesium (mg l-1) & 51 & 58 & 63 \\
\hline
\end{tabular}

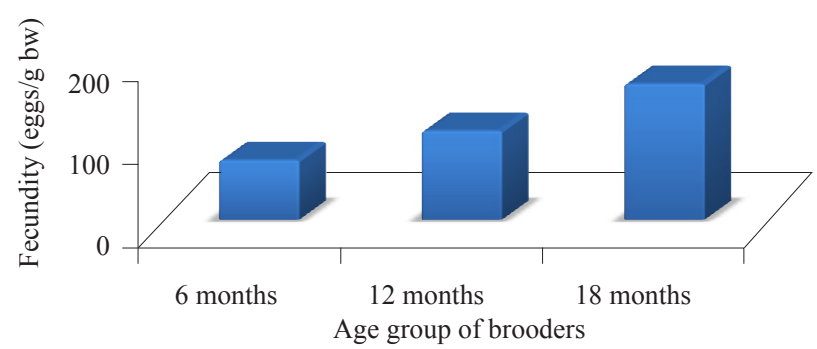

Fig. 3. Effect of age on the fecundity of C. carpio brooders

of the spermatozoa of fresh milt was affected when the milt was diluted at different dilution ratios.

The mean motility duration values recorded were significantly different $(\mathrm{p}<0.05)$ between milt collected from brooders of different age groups with highest duration $(69.66 \pm 4.72 \mathrm{sec})$ observed in the milt collected from 12 months old brooder. As it can be seen from (Table 1), the duration was the lowest in 18 months old brooder. Among the dilution ratios, 1:40 alone gave the highest mean motility duration in all the age groups. The motility score was 10 in milt produced by 12 months old brooder whereas it was 9 in other two age group brooders (Table 2).

Highest mean fertilisation percentage of $91.3 \pm 3.05 \%$ was obtained from 12 months old brooders (dilution ratio $1: 40$ ) with mean hatching rate of $76.5 \pm 2.64 \%$. Brooders of 18 months old exhibited lowest mean fertilisation rate of $67.8 \pm 4.5 \%$ at $1: 120$ dilution ratio. The lowest mean hatching rate was produced by 6 months old brooder with milt diluted at 1:120 ratio (Table 3 ). The fertilisation and hatching rates were significantly $(\mathrm{p}<0.05)$ different between different age group brooders and dilution ratios.

\section{Discussion}

Sperm density of common carp collected from brooders of three age groups and diluted at three dilution ratios, ranged between 0.2 and $1.1 \times 10^{10}$ cells $\mathrm{ml}^{-1}$ of milt. Six months old brooders had milt with high density of $1.107 \pm 0.13 \times 10^{10}$ cells $\mathrm{ml}^{-1}$. However, the lowest sperm density $\left(0.5 \pm 1.43 \times 10^{10}\right.$ cells $\left.\mathrm{ml}^{-1}\right)$ was produced by 18 months old brooder (Fig. 1). From these observations,

Table 2. Motility duration (s) and score of milt diluted with freshwater fish saline

\begin{tabular}{|c|c|c|c|c|c|c|}
\hline \multirow{3}{*}{ Dilution ratio } & \multicolumn{6}{|c|}{ Age group } \\
\hline & \multicolumn{2}{|c|}{6 months } & \multicolumn{2}{|c|}{12 months } & \multicolumn{2}{|c|}{18 months } \\
\hline & Duration & Score & Duration & Score & Duration & Score \\
\hline $1: 40$ & $61.66 \pm 1.52$ & 9 & $69.66 \pm 4.72 *$ & 10 & $59 \pm 4$ & 9 \\
\hline $1: 80$ & $60.33 \pm 1.15$ & 9 & $66.66 \pm 3.78$ & 10 & $56.33 \pm 3.05$ & 9 \\
\hline $1: 120$ & $57 \pm 1$ & 9 & $53 \pm 5$ & 10 & $54.66 \pm 2.51$ & 9 \\
\hline
\end{tabular}

$(\mathrm{p}<0.05)$ 
Table 3. Fertilisation rate (FR) and hatching rate (HR) of eggs fertilised with milt from common carp brooders of three age groups at three dilution ratios

\begin{tabular}{|c|c|c|c|c|c|c|}
\hline \multirow{3}{*}{ Dilution ratio } & \multicolumn{6}{|c|}{ Age group } \\
\hline & \multicolumn{2}{|c|}{6 months } & \multicolumn{2}{|c|}{12 months } & \multicolumn{2}{|c|}{18 months } \\
\hline & FR (\%) & HR (\%) & FR (\%) & HR (\%) & FR (\%) & HR (\%) \\
\hline $1: 40$ & $79.2 \pm 2.51$ & $54.1 \pm 1.15$ & $91.3 \pm 3.05 *$ & $76.5 \pm 2.64 *$ & $72.6 \pm 2$ & $68.8 \pm 3.51$ \\
\hline $1: 80$ & $75.5 \pm 1.52$ & $61.3 \pm 3$ & $89.1 \pm 3$ & $73.9 \pm 1.73$ & $68.6 \pm 3.78$ & $62.3 \pm 2.08$ \\
\hline $1: 120$ & $69.1 \pm 2.08$ & $49.8 \pm 1.52$ & $86.6 \pm 1.52$ & $68.2 \pm 1$ & $67.8 \pm 4.5$ & $57.4 \pm 1.52$ \\
\hline
\end{tabular}

$(\mathrm{p}<0.05)$

it is clear that sperm density decreased with increase in age as opined by Tekin et al. (2003) and Aliniya et al. (2013). Variations in the sperm density might be due to differences in individuals, fish size and season as noted by Glogowski et al. (1999). Spermatozoa concentration is known to vary with respect to different age groups (Zuromska, 1981; Buyukhatipoglu and Holtz, 1984).

The highest spermatocrit value of $84 \pm 2.5 \%$ was found in 6 months old brooder. The value was lower in 18 months old brooder $(73 \pm 1.5 \%)$ as it could be seen from Fig. 2. The results fall in line with Liley et al. (2002) and Tekin et al. (2003) who reported that spermatocrit value decreases with increasing age.

The $\mathrm{Mg}^{2+}$ value in the present study was in the range of 51-63 $\mathrm{mg} \mathrm{l}^{-1}$ and $\mathrm{Ca}^{2+}$ value was in the range of 57-69 $\mathrm{mg} \mathrm{l}^{-1}$ (Table 1). The values were significantly different between different age group of brooders $(\mathrm{p}<0.05)$. The results are similar to the reports by Ciereszko et al. (2000) who found that calcium and magnesium ions ranged from 1 to $2 \mathrm{mM}$. In the present study, the $\mathrm{Mg}^{2+}$ level in the milt was $63 \mathrm{mg} \mathrm{l}^{-1}$ in 18 months old brooder which decreased to $51 \mathrm{mg} \mathrm{l}^{-1}$ in 6 months old brooder. This is in agreement with the findings of Aas et al. (1991) that composition of seminal fluid changes in respect to age. $\mathrm{Ca}^{2+}$ level in the study were at its maximum of $69 \mathrm{mg} \mathrm{l}^{-1}$ in 18 months old brooder whereas it was only $57 \mathrm{mg} \mathrm{l}^{-1}$ in 6 months old brooder. It is in accordance with Chitsaz et al. (2012) who mentioned that as age increases, calcium level in the seminal plasma of common carp also increases and the increase was significant. Biochemical evaluation of seminal plasma is an important criterion for assessment of milt quality (Billard et al., 1995). $\mathrm{Ca}^{2+}$ and $\mathrm{Mg}^{2+}$ are important components in the seminal plasma of common carp. Freezing and thawing causes an increase of $\mathrm{Na}^{+}$ and $\mathrm{Ca}^{2+}$ and decrease of $\mathrm{K}^{+}$and $\mathrm{Mg}^{2+}$ which might be a possible reason for reduction in the fertilising capacity of cryopreserved spermatozoa (Kurokura et al., 1980).

The fecundity of common carp in the three age groups varied significantly $(\mathrm{p}<0.05)$. Fecundity of 6 months old brooder was 71 eggs per $\mathrm{g}$ body weight of fish whereas it was 106 eggs per g body weight at 12 months and 162 eggs per g body weight at 18 months (Fig. 3). This increase in fecundity is as reported by Reznick et al. (2002) and are similar to that reported by Parameswaran et al. (1972) who observed the fecundity of farmed common carp in India as around 15500 eggs per kg body weight. Similarly, Dobriyal et al. (1990) reported the fecundity of common carp to be in the range of 9927-104884 eggs per $\mathrm{kg}$ body weight.

The mean motility duration of fresh milt collected from 6,12 and 18 months old brooders were $65.89 \pm 1.52$, $73 \pm 2$ and $62.33 \pm 1.02 \mathrm{sec}$ respectively (Table 1). These differences in motility duration of undiluted milt samples was supported by Keeran and Woods (2002) who stated that the mean percentages of motile sperm obtained from the initially collected fresh, undiluted milt changed significantly over the course of the spawning season.

The highest mean motility duration of fresh milt of $73 \pm 2 \mathrm{sec}$ was noticed in milt collected from 12 months old brooder. Upon dilution with FFS at a ratio of 1:40, the value dropped to the mean motility duration of $72.3 \pm 3.0 \mathrm{sec}$. This can be vouched by the fact that motility decreases immediately after dilution (Sahin et al., 2013; Mostafapor and Ardebili, 2014).

Motility duration was highest in milt collected from 12 months old brooder (Table 2). The reason for this might be the age of the brooders as mentioned by Vuthiphandchai and Zohar (1999). Reduction in milt quality throughout the spawning season is a common factor (Legendre and Billard, 1980; Piironen, 1985; Munkittrick and Moccia, 1987; Aas et al., 1991) due to aging of spermatozoa (Rana, 1995; Suquet et al., 1998; Babiak, 2006). Legendre and Billard (1980) reported that the ability of spermatozoa to tolerate the stress of freezing and thawing may be altered during the course of spawning.

In the present study, the $\mathrm{Ca}^{2+}$ and $\mathrm{Mg}^{2+}$ values were higher for 18 months old brooder. From the reports it can be seen that, motility duration increases when there is increase in $\mathrm{Ca}^{2+}$ level (Alavi and Cosson, 2006; Islam and Akhtar, 2011; Khara et al., 2014). Contradictory to this, the motility duration was higher in 12 months old brooder (73 $\pm 2 \mathrm{sec}$ ) for which the $\mathrm{Ca}^{2+}$ level was $64 \mathrm{mg} \mathrm{l}^{-1}$. Brooders 
of 18 months had $\mathrm{Ca}^{2+}$ level of $69 \mathrm{mg} \mathrm{l}^{-1}$ with motility duration of $62.33 \pm 1.02 \mathrm{sec}$ (Table 1). No seasonal influence was observed in the present study because common carp may spawn throughout the year in tropical areas of India, with peaks in January-March and July-August (FAO). The milt collection from 6,12 and 18 months old brooder falls in the months of March, September and April respectively. Hence the spermatological properties of milt from brooders of different age group are not influenced by season.

From Table 2, it could be said that milt diluted at 1:40 ratio alone exhibited high motility duration. This is because at higher cell concentrations, the motility of milt significantly decreases, which is attributed to cell compression because of limited intracellular space (Sader et al., 2011). In support to this, Jing et al. (2009) reported that motility decreased with increased dilution.

Highest mean fertilisation $(91.3 \pm 3.05 \%)$ and mean hatching rates $(76.5 \pm 2.64 \%)$ were obtained from 12 months old brooders, when milt was diluted at 1:40 ratio. Other age group brooders and dilution ratios produced comparatively low fertilisation/hatching rates and the values were significantly different $(p<0.05)$. The difference in the fertilisation and hatching percentages between brooders of different age groups might be due to the poor quality of milt from 6 and 18 months old brooders which directly reflected on low fertilisation and hatching rates as discussed by various researchers (Methven and Crim, 1991; Shangguan and Crim, 1995; Suquet et al., 1998).

The fertilisation rate was found to decrease with increasing dilution ratios. This fact was vouched by Cognie et al. (1989) who found that the motility and fertility of deep frozen spermatozoa of $C$. carpio were significantly improved when the dilution ratio was reduced from 1:100 to 1:2. According to Rana and Mc Andrew (1989) and Gwo et al. (1991) the milt dilution ratio had strong effect on fertility. There was significant difference $(p<0.05)$ between the fertilisation and hatching rates of different age group brooders and between different dilution ratios.

Hence based on the present study it is advised to use common carp males and females of 12 months age for higher fertilisation success as they produced good quality milt in terms of motility duration, fertilisation and hatching rates.

\section{Acknowledgements}

University Grants Commission, New Delhi is greatly acknowledged for providing funding support through Maulana Azad National Fellowship to carry out the research work.

\section{References}

Aas, G. H., Refstie, T. and Gjerde, B. 1991. Evaluation of milt quality of Atlantic salmon. Aquaculture, 95:125-132.

Akcay, E., Bozkurt, Y., Secer, S. and Tekin, N. 2004 Cryopreservation of mirror carp sperm. Turk. J. Vet. Anim. Sci., 28(5): 837-843.

Alavi, S. M. H. and Cosson, J. 2006. Sperm motility in fishes. (II) Effects of ions and osmolality: A review. Cell Biol. Int., 30: 1-14.

Aliniya, M., Khara, H., Noveiri, S. B. and Dadras, H. 2013. Influence of age of common carp (Cyprinus carpio) broodstock on reproductive traits and fertilisation. Turk. $J$. Fish. Aquat. Sci., 13: 19-25.

Aral, F., Erdinc, S. and Zafer, D. 2007. A study on the milt quality of Oncorhynchus mykiss (Walbaum, 1972) and Carasobarbus luteus (Heckel, 1843) in Atatürk Dam Lake, south-eastern Turkey. Turk. J. Fish. Aquat. Sci., 7: 41-44.

Babiak, I. 2006. Quantitative characteristics of Atlantic halibut, Hippoglossus hippoglossus L., semen throughout the reproductive season. Therio., 65: 1587-1604.

Betsy, C. J. and Stephen, J. S. K. 2014. New classification of motility score in fishes to determine the quality of spermatozoa. Int. J. Fish. Aquat. Stud., 1(4): 20-13.

Billard, R., Cosson, J., Perchec, G. and Linhart, O. 1995. Biology of sperm and artificial reproduction in carp. Aquaculture, 124: $95-112$

Bozkurt, Y., Yavas, I. and Karaca, F. 2012. Cryopreservation of brown trout (Salmo trutta macrostigma) and ornamental koi carp (Cyprinus carpio) sperm. In: Igor Katkov, (Ed.), Current frontiers in cryopreservation, InTech, p. 293-304.

Bromage, N. and Cumaranatunga, R. C. 1988. Egg production in the rainbow trout. In: Muir, J. F. and Roberts, R. J. (Eds.), Recent advances in aquaculture. Croom Helm, London, p. 63-138.

Brooks, S., Tyler, C. R. and Sumpter, J. P. 1997. Egg quality in fish: what makes a good egg? Rev. Fish Biol. Fish., 7: 387-416.

Buyukhatipoglu, S. and Holtz, W. 1984. Sperm output in rainbow trout (Salmo gairdneri) effect of age, timing and frequency of stripping and presence of females. Aquaculture, 37: 63-71.

Cabrita, E., Anel, L. and Herraez, P. M. 2001. Effect of external cryoprotectants as membrane stabilisers on cryopreserved trout sperm. Therio., 56: 623-635.

Chitsaz, H., Ziaei, R. and Akrami, R. 2012. Evaluation of sperm quality of common carp (Cyprinus carpio) by use of seminal plasma parameters in the south-east of the Caspian Sea, Golestan Province. J. Fish., 3(23): 69-80.

Ciereszko, A., Glogowski, J. and Dabrowski, K. 2000. Biochemical characteristics of seminal plasma and spermatozoa of freshwater fishes. In: Tiersch, T. R. and Mazik, P. M. (Eds.), Cryopreservation in aquatic species. 
World Aquaculture Society, Baton Rogue, Louisiana, p. 20-48.

Cognie, F., Billard, R. and Chao, N. H. 1989. Freezing of the milt of the common carp, Cyprinus carpio. J. Appl. Ichthyol., 5: $165-176$

Dobriyal, A. K., Bahuguna, A. K., Kotnala, C. B., Kumar, N. and Singh, H. R. 1990. A case study on the reproductive capacity of common carp (Cyprinus carpio) from India. Acta Societatis Zoologicae Bohemicae, 54: 91-96.

FAO 2015. Fishery and aquaculture statistics. Food and Agriculture Organisation of the United Nations, Rome.

Glogowski, J., Babiak, I., Kucharczyk, D., Lucznski, M. and Piros, B. 1999. Some properties of bream Abramis brama L. sperm and its cryopreservation. Aquac. Res., 30: 765-772.

Gwo, J. C., Strawn, K., Longnecker, M. J. and Arnold, C. R. 1991. Cryopreservation of Atlantic croaker spermatozoa. Aquaculture, 94: 355-375.

Hafez, E. S. E., 1987. Reproduction in farm animals. $5^{\text {th }}$ edn., Lea and Febiger, Philadelphia, USA, p: 315-481.

Hanjavanit, C., Kitancharoen, N. and Rakmanee, C. 2008. Experimental infection of aquatic fungi on eggs of African catfish (Clarias gariepinus Burch). KKU Sci., 36: 36-43.

Islam, M. S. and Akhter, T. 2011. Tale of fish sperm and factors affecting sperm motility: A review. Adv. Life Sci., 1(1): 11-19.

Jing, R., Huang, C., Bai, C., Tanguay, R. and Dong, Q. 2009. Optimisation of activation, collection, dilution and storage methods for zebrafish sperm. Aquaculture, 290: 165-171.

Keeran, K. J. and Woods, L. C. 2002. An evaluation of extenders for the short-term storage of striped bass milt. North Am. J. Aquac., 64: 248-256.

Khara, H., Noveiri, S. B., Rahbar, D. H. M., Ahmadnejad, M. and Khodadoost, A. 2014. Effect of different activation solutions on motility and fertilising ability of spermatozoa in common carp Cyprinus carpio Linnaeus, 1758. Indian J. Fish., 61(3): 63-68.

Kjorsvik, E. and Lonning, S. 1983. Effects of egg quality on normal fertilisation and early development of the cod, Gadus morhua L. J. Fish Biol., 23: 1-12.

Kurokura, H., Hirano, R. and Tomita, M. 1980. Cryopreservation of rainbow trout sperm. Bull. Jap. Soc. Sci. Fish., 46: 1493-1495.

Kurokura, H., Hirano, R., Tomita, M. and Iwahashi, M. 1984. Cryopreservation of carp sperm. Aquaculture, 37: 267-273.

Legendre, M. and Billard, R. 1980. Cryopreservation of rainbow trout sperm by deep-freezing. Rep. Nut. Dev., 20: $1859-1868$.

Liley, N. R., Tamkee, P., Tsai, R. and Hoysak, D. J. 2002. Fertilisation dynamics in rainbow trout (Oncorhynchus mykiss): Effect of male age, social experience and sperm concentration and motility on in vitro fertilisation. Can. J. Fish. Aquat. Sci., 59: 144-152.

Lubzens, E., Daube, N., Pekarskay, I., Magnus, Y., Cohen, A., Yuesefovich, F. and Feigin, P. 1997. Carp (Cyprinus carpio L.) spermatozoa cryobanks - Strategies in research and application. Aquaculture, 155: 13-30.

Methven, D. A. and Crim, L. W. 1991. Seasonal changes in spermatocrit, plasma sex steroids and motility of sperm from Atlantic halibut (Hippoglossus hippoglossus). In: Scott, A. P., Sumpter, J. P., Kime, D. E., Rolfe, M. S. (Eds.), Proceedings of the $4^{\text {th }}$ International Symposium on Reproductive Physiology of Fish. Sheffield, 170 pp.

Mostafapor, S. and Ardebili, F. F. 2014. Effects of diluting medium and holding time on sperm motility analysis by CASA in ram. Vet. Res. Forum, 5(2): 101-105.

Munkittrick, K. and Moccia, D. 1987. Seasonal changes in the quality of rainbow trout (Salmo gairdneri) semen: effect of delay in stripping on spermatocrit, motility, volume and seminal plasma constituents. Aquaculture, 64: 147-156.

Parmeswaran, S., Alikunhi, K. H. and Sukumaran, K. K. 1972. Observations on the maturation, fecundity and breeding of common carp, Cyprinus carpio. Indian J. Fish., 19: $110-124$

Piironen, J. 1985. Variation in the properties of milt from the Finnish landlocked salmon (Salmo salar m. sebago Girard) during a spawning season. Aquaculture, 48: 337-350.

Rana, K. J. and McAndrew, B. J. 1989. The viability of cryopreserved tilapia spermatozoa. Aquaculture, 76: $335-345$

Rana, K. 1995. Preservation of gametes. In: Bromage, N. R. and Roberts, R. J. (Eds.), Broodstock management and egg and larval quality. Cambridge University Press, Cambridge, p. 53-76.

Reznick, D., Ghalambor, C. and Nunney, L. 2002. The evolution of senescence in fish. Mech. Aging Dev., 123: 773-789.

Rurangwa, E., Kime, D. E., Olevier, F., Nash, J. P. 2004. The measurement of sperm motility and factors affecting sperm quality in cultured fish. Aquaculture, 234: 1-28.

Sahin, T., Kurtoglu, I. Z. and Balta, F. 2013. Effect of different extenders and storage periods on motility and fertilisation rate of rainbow trout (Oncorhynchus mykiss) semen. Univ. J. Agri. Res., 1(3): 65-69.

Sarder, M. R. I., Rahman, A. K. M. A., Samad, M. S., Nazrul, K. M. S. and Bhuiyan, M. K. J. 2011. Cryopreservation of sperm of Labeo rohita (Hamilton, 1822) and its use in fertilisation and hatching of eggs. Prog. Agri., 22(1 and 2): 123-137.

Secer, S., Tekin, N., Bozkurt, Y., Bukan, N. and Akcay, E. 2004. Correlation between biochemical and spermatological parameters in rainbow trout (Oncorhynchus mykiss) semen. Israeli J. Aquac., 56(4): 274-280. 
Shangguan, B. and Crim, L. W. 1995. The effect of stripping frequency on the sperm quantity and quality in winter flounder, Pleuronectes americanus. In: Goetz, F. W. and Thomas, P. (Eds.), Proceedings of the Fifth International Symposium on Reproductive Physiology of Fish. Austin, p. 142.

Siraj, S. S., Smitherman, R. O., Castillo-Galusa, S. and Dunham, R. A. A. 1983. Reproductive traits for three-year classes of Tilapia nilotica and maternal effects on their progeny. In: Fishelson, L. and Yaron, Z. (Eds.), International Symposium on Tilapia in Aquaculture. Tel Aviv University, Tel Aviv, Israel, p. 210-218.

Springate, J., Bromage, N., Elliot, J. A. K. and Hudson, D. H. 1984. The timing of ovulation and stripping and their effects of fertilisation and survival to eying hatch and swim-up in the rainbow trout (Salmo gairdnerii, R.). Aquaculture, 43: 313-322.

Sultana, M., Nahiduzzaman, M., Hassan, M. M., Khanam, M.U.H. and Hossain, M. A. R. 2010. Fertility of cryopreserved common carp (Cyprinus carpio) spermatozoa. Univ. J. Zool. Rajshahi Univ., 28: 51-55.

Suquet, M., Dreanno, C., Dorange, G., Normant, Y., Quemener, L., Gaignon, J. L. and Billard, R. 1998. The ageing phenomenon of turbot spermatozoa: effects on morphology, motility and concentration, intracellular ATP content, fertilisation and storage capacities. J. Fish Biol., 52: 31-41.
Tekin, N., Secer, S., Akcay, E., Bozkurt, Y. and Kayam, S. 2003. The effect of age on spermatological properties in rainbow trout (Oncorhynchus mykiss W. 1792). Turk. J. Vet. Anim. Sci., 27: 37-44.

Tempero, G. W., Ling, N., Hicks, B. J. and Osborne, M. W. 2006. Age composition, growth, and reproduction of koi carp (Cyprinus carpio) in the lower Waikato region, New Zealand. New Zealand J. Mar. Freshw. Res., 40(4): 571-583.

Thomas, P. C., Rath, S. and Mohapatra, K. D. 2003. Breeding and seed production of fin fish and shell fish. Daya Publishing House, Delhi, 402 pp.

Trippel, E. A. and Neilson, J. D. 1992. Fertility and sperm quality of virgin and repeat-spawning Atlantic cod (Gadus morhua) and associated hatching success. Can. J. Fish. Aquat. Sci., 49: 2118-2127.

Verma, D. K., Routray, P., Dash, C., Dasgupta, S. and Jena, J. K. 2009. Physical and biochemical characteristics of semen and ultrastructure of spermatozoa in six carp species. Turk. J. Fish. Aquat. Sci., 9: 67-76.

Vuthiphandchai, V. and Zohar, Y. 1999. Age-related sperm quality of captive striped bass Morone saxatilis. J. World Aquac. Soc., 30: 65-72.

Zuromska, H. 1981. Effect of different thermal regimes on reproductive cycles of tench, Tinca tinca (L.). Part VI. Estimation of milt quality. Polish Arch. Hydrobiol., 28: 229-241. 